\title{
Ferric Ion-Charged NTA-Agarose
}

National Cancer Institute

\section{Source}

National Cancer Institute. Ferric Ion-Charged NTA-Agarose. NCI Thesaurus. Code C161865.

A cross-linked agarose matrix linker-bound to nitrilotriacetic acid (NTA) and charged with ferric ions. This reagent is used in immobilized metal affinity chromatography for the purification of proteins or peptides from a biological sample. 